\title{
Correlación de requisitos para la integración de la gestión en las entidades públicas Colombianas ${ }^{*}$
}

\author{
Correlation of requirements for management \\ integration in Colombian public entities
}

\section{Correlação dos requisitos para a inteǵração da gestão nas entidades públicas colombianas}

Recibido: 14 de marzo de 2018

Revisado: 28 de marzo de 2018

Aceptado: 27 de mayo de 2018

Claudia Patricia Crü Amérquita"

Administradora Colombiana de Pensiones - Colpensiones

Luis Antonio Sarmiento Melo ${ }^{* *}$

Ministerio de Comercio, Industria y Turismo

Jairo Alonso Sáenz Gómez ${ }^{* * *}$

Ministerio de Ambiente y Desarrollo Sostemible

Ximena Lucía Pedraza Najar ${ }^{* * * *}$

Universidad Santo Tomás en convenio con ICONTEC

* Artículo de resultado de investigación. DOI: http://dx.doi.org/10.15332/s2145-1389.2018.0001.01

** Administradora de empresas. Especialista en Administración y Gerencia de Sistemas de Calidad. Especialista en Formulación y Evaluación de Proyectos. Magíster en Calidad y Gestión Integral. Correo electrónico: claudiapatricia.cruz@hotmail.com; claudia.cruz@usantotomas.edu.co

*** Administrador de empresas. Especialista en Administración y Gerencia de Sistemas de Calidad. Especialista en Gerencia Estratégica. Magíster en Calidad y Gestión Integral. Correo electrónico: luissarm@gmail.com; luis.sarmiento@usantotomas.edu.co

**** Ingeniero Químico. Especialista en Administración y Gerencia de Sistemas de Calidad. Magíster en Calidad y Gestión Integral. Auditor de control interno y HSEQ. Correo electrónico: eng.saenz@gmail.com; jairosaenz@usantotomas.edu.co

${ }^{* * * * *}$ Doctora en Administración. Magíster en Calidad y Gestión Integral. Microbióloga Industrial. Especialista en Gestión de la Producción, la Calidad y la Tecnología. Especialista en Gerencia de Procesos, Calidad e Innovación. Docente investigadora del Convenio USTA - ICONTEC en la línea de investigación en Educación y en Gestión del Conocimiento. Auditora en sistemas de gestión y consultora organizacional. Correo electrónico: ximenapedraza@usantotomas.edu.co,ximena.pedraza@yahoo.com 


\section{RESUMEN}

En Colombia la gestión pública exige una transformación gerencial que le facilite al Estado implementar políticas focalizadas hacia el mejoramiento de la calidad de vida de los ciudadanos. La inexistencia de técnicas para la integración de la gestión en las entidades públicas impulsa la investigación que conlleva al diseño de una metodología para la integración de la gestión. Con un enfoque mixto y un alcance exploratorio secuencial, se establece la correlación existente entre los requisitos de las normas técnicas ISO 9001:2015, ISO 14001:2015 y los modelos normativos Decreto 1072 de 2015 (SG-SST), Decreto 943 de 2014 (MECI:2014) y Decreto 2482 de 2012 (MIPG:2012), obteniendo como resultado la matriz de correlación, producto de la revisión bibliográfica y la lectura crítica de las normas técnicas y los modelos normativos del Estado. A partir de esta matriz correlacional, se desarrollaron contenidos descriptivos, tomados como base para la construcción de encuestas de percepción, aplicando métodos estadísticos que sustentan el grado de correlación de los requisitos mediante el coeficiente de correlación de Spearman y la confiabilidad de los datos mediante el alfa de Cronbach, validando así el contenido de la matriz, que se constituye en referente orientador para la integración de sistemas de gestión en las entidades públicas.

Palabras clave: ISO 9001, ISO 14001, MECI, MIPG, SG-SST, sistemas de gestión integrados.

\section{ABSTRACT}

In Colombia, public management requires a managerial transformation that facilitates the State to implement policies focused on improving the quality of life of citizens. The lack of techniques for management integration in public entities drives the research that leads to the design of a methodology for integration management. With a mixed approach and a sequential exploratory scope, the existing correlation between the requirements of the technical standards ISO 9001: 2015 (QMS), ISO 14001: 2015 (EMS) and the normative models Decree 1072 of 2015 (OHSMS), MECI: 2014 (Internal Control Standard Model) and MIPG: 2012 (Planning and Management Integrated Model), obtaining as a result the correlation matrix, product of the bibliographic review and the critical reading of the technical standards and the normative models of the State. From this correlation matrix, descriptive contents were developed, taken as a basis for the construction of perception surveys, applying statistical methods that support the degree of correlation of the requirements through Spearman's correlation coefficient and the reliability of the data through Cronbach's alpha, thus validating the content of the matrix, which is a guiding reference for the integration of management systems in public entities.

Keywords: Integrated management systems, ISO 9001, ISO 14001, SICM-MECI, IPMM-MIPG, OHSMS.

\section{RESUMO}

$\mathrm{Na}$ Colômbia a gestão pública exige uma transformação gerencial que facilite ao Estado implementar políticas focadas no melhoramento da qualidade de vida dos cidadãos. A inexistência de técnicas para a integração da gestão nas entidades públicas impulsiona a pesquisa que acarreta a criação de uma metodologia para a integração da gestão. Com um enfoque misto e um alcance exploratório sequencial, se estabelece a correlação existente entre os requisitos das normas técnicas ISO 9001:2015, ISO 14001:2015 e os modelos normativos Decreto 1072 de 2015 (SG-SST), Decreto 943 de 2014 (MECI: 2014) e Decreto 2482 de 2012 (MIPG: 2012), 
obtendo como resultado a matriz de correlação, produto da revisão bibliográfica e a leitura crítica das normas técnicas e dos modelos normativos do Estado. A partir dessa matriz correlacional, se desenvolveram conteúdos descritivos, tomados como base para a construção de pesquisas de opinião e de percepção, aplicando métodos estatísticos que sustentam 0 grau de correlação dos requisitos por meio do coeficiente de correlação de Spearman e a confiabilidade dos dados mediante 0 alfa de Cronbach, validando assim o conteúdo da matriz, que se constitui como referente orientador para a integração de sistemas de gestão nas entidades públicas.

Palavras-chave: ISO 9001, ISO 14001, MECI, MIPG, SG-SST, sistemas de gestão integrados.

\section{INTRODUCTION}

Organizations constantly adopt technical standards in management systems such as ISO 9001, ISO 14001, OHSAS 18001, ISO/IEC 27001, ISO 22000, among others, with the purpose improving their competitiveness and achieving excellence. The Colombian public sector has not been oblivious to this reality, a fact that has led managers of public entities to incorporate various management systems into them, as well as to comply with legislation, which adopts international technical standards, adjusting them to the local environment and some of them raised to the level of the Law as it happens with the normative models OHSMS (Decree 1072, 2015), Internal Control Standard Model (Administrative Department of Public Function, 2014) and Planning and Management Integrated Model (MIPG:2012) (Decree 2482, 2012).

The implementation of the systems is not conceived by senior management as the adoption of management tools that allow the success of the organizational strategic direction and on the contrary they have been stigmatized as impositions generated by new regulations and legal decisions, which entail its implementation independently, without facilitating the identification of impacts in different direct interaction approaches: health, occupational safety, environmental and quality attributes, for instance. Likewise, ignoring the postulate of Bernardo, who considers the integration of management systems as the best management practice when an organization has multiple systems (2014).

In this sense, the implementation of management systems and normative models focuses on the compliance of requirements, implemented and controlled separately, without recognizing the interactions that occur between them. However, the challenge is being conceived to visualize and recognize them beyond the fulfillment of the requirements of a management system, an aspect that allows the identification of common elements that can be integrated in the management of the entity, thus avoiding having approaches of separate systems. Rebelo, Santos \& Silva (2014) affirm that from a proper integrated management system, the organization obtains competitive advantages, optimizes its resources and adequately manages its risks, a postulate that is corroborated by Bonilla-Palacios \& Martínez-García (2015).

Vieira, Ferreira, \& De Oliveira (2016), indicate that certified management systems, such as ISO 9001 Quality Management System, ISO 14001 Environmental Management System and the Occupational Health and Safety Management System OHSAS 18001 have gained popularity in different countries around the world. Likewise, they affirm that one way to improve the efficiency of integrated management system is to address them jointly.

Given this panorama, after the bibliographic review on management integration methodologies and in spite 
of the legal dispositions issued by the Administrative Department of Public Function (DAFP) and the proposed in article 133 of the National Development Plan 2014-2018 (Law 1753, 2015) in matters of integration of management systems, it is established that currently there is no methodology that from the strategic direction of public entities in Colombia enables integrating their management, with normative models ISO 14001:2015 (EMS), ISO 9001:2015 (QMS), OHSMS Decree 1072 of 2015 (OHSMS), MECI:2014 (Internal Control Standard Model) and MIPG:2012 (Planning and Management Integrated Model), situation that leads to particularization and empiricism in each of them and from their internal control coordination committees (DAFP, 2014) to look for mechanisms to articulate the technical and regulatory management models, leading to duplication of efforts and inefficiencies.

This situation leads to this research that seeks to propose a methodology for management integration, as an alternative solution to the problem of state entities, for not having guiding guidelines in the implementation of various systems, while considering the commitments of competitiveness acquired by the State before the Organization for Economic Cooperation and Development (OECD, 2016). In this context, public management stands out as one of the main indicators in which the result of the application of the proposed methodology has an impact, based on the premise that public management is good if it satisfactorily satisfies the parameters of integrity, efficiency, effectiveness, equality and equity, referenced to a positive impact on social development and the quality of life of people (CLAD, 2009).

The research is developed identifying three objectives, through which response is given to the prevailing need to integrate management in public entities in
Colombia. The first one consists in determining the correlation and transversality of the requirements of the ISO technical standards with the normative models of the State OHSMS, MECI and MIPG. Then the guidelines that allow the design of the methodology for the integration of the management systems are established and finally the content of the design of the proposed methodology is validated through the validation of experts, thus obtaining the final product consisting of the methodology for management integration in public entities based on the OHSMS, EMS, QMS, MECI:2014 and MIPG:2012 models.

In this regard, the importance of this research in the field of management integration, lies in the systematic process pursued for the formulation of the proposed methodology, aligned with the spiral of continuous improvement and which starting point is the correlation matrix structured under the mainstay of the QMS considered the international reference of the ISO quality management system (Camisón et al., 2009). As the ISO 9001:2015 contemplates, the high-level structure is immersed within the PDCA cycle, as chapters 4, 5 and 6 correspond to the planning phase, 7 and 8 to the do phase, 9 to the check phase and 10 to the act phase.

The fundamental contribution of the research process consists of having a tool for public entities that allows them to systematically comply with the implementation of management models, in accordance with the requirements of the modernization of the State and world reality.

This document illustrates the results of the research in relation to the first objective in reference to the correlation and transversality of the requirements of the ISO technical standards with the normative models of the State OHSMS, MECI and MIPG. 


\section{METHODOLOGY}

The methodology adopted for the research is conceived under the pragmatism approach, as it aims to solve problems in a context in which there is no previous research; framed in a sequential exploratory scope, since it is based on proposing a form of management integration on which there is no bibliographic information. The methodological design is a sequential exploratory design -Dexplos- (Hernández, Fernández, \& Baptista, 2014), taking into account that the information gathering process was carried out qualitatively and the analysis of information links quantitative data.

To achieve the first objective of the research, we began with the bibliographic review, which allowed us to investigate in the Latin American and Colombian context about the existence of models for the integration of management systems in public entities, consulting various data bases such as Science Direct, Scopus and Redalyc. Likewise, by broadening the consultation reference to the Latin American context, a telephone interview was conducted to an expert on issues of quality management systems in Mexico (Hidalgo, Telephone communication with Management and Assurance Director of the Mexican Institute of Standardization, 2016).

The critical reading of the technical standards ISO 9001:2015, ISO 14001:2015 and the normative models OHSMS, MECI:2014 and MIPG:2012 and the analytical reading of the high-level structure (Annex SL) issued by the ISO (ISO, 2014) were then carried out. Based on the review and analysis of the aforementioned standards and models, the equivalences and common elements shared by each of them from each phase of continuous improvement were determined, designing the correlational matrix (Hernández, Fernández \& Baptista, 2014), process that led to select as integrating axis the requirements of the NTC-ISO 9001:2015 for being the international reference of the quality management system, taking into account that the purpose of any organization from its mission and vision is to satisfy needs of users and stakeholders, which is what allows the sustainability of the organization (Bernardo et al., 2017).

Next, the intervention variables were defined for the design of four structured surveys, with closed questions (Hernández, Fernández \& Baptista, 2014), which by means of a Likert scale measured the degree of perception of the correlation of requirements the people who interact with management systems have.

After designing the surveys using the Google Forms platform, the pre-validation stage was continued by the researchers, generating technical contributions that allowed making writing, spelling and presentation corrections, as well as the verification of access links and duration of completion of each survey.

The surveys were applied to a population of 42 people, selected by convenience, to establish the type of survey to fill out, giving priority to 3 aspects for their selection: career, work experience in the public sector and experience in quality and other management systems, with educational levels between technologist

Table 1. Survey application

\begin{tabular}{|l|c|c|c|c|}
\hline Respondents vs. surveys & $\begin{array}{c}\text { NTC ISO 9001:2015 } \\
\text { and OHSMS }\end{array}$ & $\begin{array}{c}\text { NTC ISO 9001:2015 } \\
\text { and NTC- } \\
\text { ISO14001:2015 }\end{array}$ & $\begin{array}{c}\text { NTC ISO 9001:2015 } \\
\text { and MECI:2014 }\end{array}$ & $\begin{array}{c}\text { NTC ISO 9001:2015 } \\
\text { and MIPG:2012 }\end{array}$ \\
\hline Respondents & 14 & 15 & 16 & 18 \\
\hline
\end{tabular}

Source: Own development. 
and doctorate. Taking advantage of the profile of some respondents, several surveys were applied, which are presented in table 1.

The information collected was subjected to manual statistical processing using the Excel sheet to obtain the validity criteria, based on the definition offered by Hernández, Fernández \& Baptista (2014), in which "validity refers to the degree to which a measuring instrument actually measures the variables it intends to measure" ( $p$ 262). In this context, two validity criteria are established: reliability obtained through Cronbach's alpha, which evaluates for the entire instrument the data obtained from each of the items around the intended results and in turn decreases the uncertainty in the interactions of the results presented for each of the participants (Hungler \& Polit, 2003). On the other hand, the correlation criterion obtained by Spearman's coefficient quantitatively describes the magnitude and direction of the relationship between different phenomena (Hungler \& Polit, 2003) and facilitates the correlation measure for variables at an ordinal measurement level, measuring the interaction of a dependent variable with an independent variable, statistically using Likert scales. The variables defined are those annotated to the management system indicated in the results section.

The processing was done using the description of the method explained step by step by Santos to perform the manual calculation. (2017, p. 6)

Table 2. Main clauses susceptible of integration

\begin{tabular}{|c|c|}
\hline MODEL & CORRELATED REQUIREMENTS \\
\hline OHSMS & 29 \\
\hline EMS & 30 \\
\hline MIPG:2012 & 35 \\
\hline MECI:2014 & 40 \\
\hline
\end{tabular}

Source: Own development.

\section{RESULTS AND DISCUSSION}

The documentary review carried out in the first instance confirmed the inexistence of methodologies for the integration of management systems in the Colombian public sector based on technical standards and normative models. From the telephone interview made to a Mexican expert, with which the Latin American context and other documentary inquiries were extended, it was established that the integration of the management systems is a voluntary issue, undertaken by the state entities, taking into account that there is no norm that forces them to integrate, nor any methodologies that guides them in said actions (Hidalgo, 2016).

Based on the analysis carried out to ISO 9001:2015, ISO 14001:2015, OHSMS, MECI:2014, MIPG:2012 and the high-level structure, the first version of the correlation matrix was constructed, in which it was defined as an integrating axis the requirements of the Quality Management System, exercise that allowed to obtain the common elements of each of the technical standards and normative models, as well as establishing differences with respect to the specific approaches of each of them, identifying that there are requirements that are not compatible due to the inherent nature each standard has, reason why they do not correlate, NR.

The matrix constructed and revised, resulted that of the 47 main clauses that contain the requirements of the technical standard ISO 9001:2015, only requirement 8.5.3 "Property belonging to external customers or suppliers" does not correlate with any clause of the standards and normative models established to integrate and the remaining 46 clauses are correlated, as evidenced in table 2:

It is identified that the normative models associated to the research correlate several clauses, as opposed to a single clause of the technical standard ISO 9001:2015, because they do not have the structure of the ISO 
Table 3. Correlated clauses - PLAN

\begin{tabular}{|c|c|c|c|c|}
\hline NTC ISO 9001:2015 & $\begin{array}{c}\text { OHSMS - DECREE } \\
1072 / 2015\end{array}$ & $\begin{array}{l}\text { NTC ISO } \\
\text { 14001:2015 }\end{array}$ & MECI:2014 & MIPG:2012 \\
\hline Clause & Clause & Clause & Clause & Clause \\
\hline 4.1 & NR & 4.1 & NR & $\mathrm{NR}$ \\
\hline 4.2 & 2.2.4.6.3 & 4.2 & $\mathrm{NR}$ & $\mathrm{NR}$ \\
\hline 4.3 & 2.2.4.6.4 & 4.3 & NR & NR \\
\hline 4.4 & NR & 4.4 & $\begin{array}{l}1.2 .5 \\
1.3 .1 \\
\end{array}$ & $\begin{array}{l}2.5 .1 \\
2.6 .4 \\
\end{array}$ \\
\hline 5.1.1 & 2.2.4.6.8 & 5.1 & 1.3.1 & 2.4.1 \\
\hline 5.1 .2 & NR & NR & $\begin{array}{c}1.3 .1 \\
2.1 .1 \\
3 \\
\end{array}$ & $\begin{array}{l}2.3 .1 \\
2.5 .1\end{array}$ \\
\hline 5.2 & $\begin{array}{l}2.2 .4 .6 .5 \\
2.2 .4 .6 .6 \\
2.2 .4 .6 .7\end{array}$ & 5.2 & $\begin{array}{l}1.1 .1 \\
1.2 .5\end{array}$ & $\begin{array}{c}2.2 \\
2.5 .1\end{array}$ \\
\hline 5.3 & $\begin{array}{l}2.2 .4 .6 .8 \\
2.2 .4 .6 .9 \\
\text { 2.2.4.6.10 } \\
\end{array}$ & 5.3 & 1.2 .3 & 2.4.1 \\
\hline 6.1 & 2.2.4.6.15 & 6.1 & $\begin{array}{l}1.2 .1 \\
1.3 .2\end{array}$ & $\begin{array}{c}2.3 .1 \\
2.5 .5 \\
3.3 \\
\end{array}$ \\
\hline 6.2 & 2.2.4.6.18 & 6.2 & $\begin{array}{l}1.1 .2 \\
1.2 .1 \\
\end{array}$ & NR \\
\hline 6.3 & 2.2.4.6.17 & 6.2 .2 & $\begin{array}{l}1.2 .1 \\
1.2 .3\end{array}$ & $\begin{array}{c}2.4 .2 \\
2.6 .4 \\
2.5 .5 \\
3.3\end{array}$ \\
\hline
\end{tabular}

Source: Own development.

standards for management systems, that is to say the high-level structure. The designed matrix is aligned with Annex SL, as indicated in tables 3, 4, 5 and 6.

From the plan phase of the spiral of continuous improvement, the correlated requirements presented in table 3 correspond to the context of the organization, leadership and planning. Its correlation allows establishing the actual condition of the entity by facilitating knowledge of the context and baseline of the organization, identifying and establishing priorities, defining responsibilities and participation of senior management, as well as having the resources in an adequate manner that enables the entity to fulfill its administrative functions and satisfy the needs and expectations of stakeholders within the legal framework.

This correlation of requirements provides the entity with the possibility of planning holistic processes, to demonstrate the inclusion of critical specifications that facilitate the integration of management systems, identify the objective of each of them and their 
managers, their scope, the activities that make possible their interactions, who, how and when they will develop the activities and the type of resources necessary to carry them out (Bernardo et al., 2015).

The do phase presents the requirements corresponding to support and operation, which makes easier to identify the people involved (with the appropriate competencies and awareness), the infrastructure, the measurement and monitoring resources, the communication and the documented information that allows reaching the organizational purposes, allowing the generation of tangible (products) and/or intangibles (services) transformations aimed at improving the quality of life, under the Latin American principles of public administration: integrity, efficiency, effectiveness, equality and equity (CLAD, 2009), in accordance with the requirements established and aligned with the regulatory plans.

Table 4. Correlated clauses - DO

\begin{tabular}{|c|c|c|c|c|}
\hline NTC ISO 9001:2015 & $\begin{array}{c}\text { OHSMS - DECREE } \\
1072 / 2015\end{array}$ & NTC ISO 14001:2015 & MECI:2014 & MIPG:2012 \\
\hline Clause & Clause & Clause & Clause & Clause \\
\hline 7.1 .1 & NR & 7.1 & $\begin{array}{l}1.2 .1 \\
1.2 .3\end{array}$ & $\begin{array}{l}2.6 .1 \\
2.6 .2 \\
2.6 .3 \\
\end{array}$ \\
\hline 7.1 .2 & NR & NR & 1.1.2 & $\begin{array}{l}2.4 .1 \\
2.4 .2 \\
2.4 .3\end{array}$ \\
\hline 7.1 .3 & NR & NR & 1.2 .1 & $\begin{array}{c}2.5 .5 \\
3.3\end{array}$ \\
\hline 7.1.4 & NR & NR & $\begin{array}{l}1.1 .1 \\
1.2 .2\end{array}$ & 2.4.4 \\
\hline 7.1 .5 & $\begin{array}{l}2.2 .4 .6 .19 \\
2.2 .4 .6 .20 \\
2.2 .4 .6 .21 \\
2.2 .4 .6 .22\end{array}$ & 9.1 .1 & 1.2 .4 & NR \\
\hline 7.1.6 & NR & NR & 1.2 .3 & 2.4.1 \\
\hline 7.2 & 2.2.4.6.35 & 7.2 & 1.1 .2 & $\begin{array}{l}2.4 .1 \\
2.4 .3\end{array}$ \\
\hline 7.3 & NR & 7.3 & $\begin{array}{l}1.1 .1 \\
1.1 .2 \\
\end{array}$ & 2.3 .4 \\
\hline 7.4 & 2.2.4.6.14 & 7.4 & 3 & 2.3 .2 \\
\hline 7.5 .1 & 2.2.4.6.12 & 7.5.1 & 3 & $\begin{array}{l}2.3 .2 \\
2.5 .6 \\
\end{array}$ \\
\hline 7.5 .2 & 2.2.4.6.12 & 7.5 .2 & 3 & $\begin{array}{l}2.3 .2 \\
2.5 .6 \\
\end{array}$ \\
\hline 7.5 .3 & 2.2.4.6.13 & 7.5 .3 & 3 & $\begin{array}{l}2.3 .2 \\
2.5 .6\end{array}$ \\
\hline
\end{tabular}




\begin{tabular}{|c|c|c|c|c|}
\hline NTC ISO 9001:2015 & $\begin{array}{c}\text { OHSMS - DECREE } \\
1072 / 2015\end{array}$ & NTC ISO 14001:2015 & MECI:2014 & MIPG:2012 \\
\hline Clause & Clause & Clause & Clause & Clause \\
\hline 8.1 & 2.2.4.6.17 & 8.1 & 1.2 .2 & $\begin{array}{l}2.3 .3 \\
2.5 .1 \\
2.5 .3\end{array}$ \\
\hline 8.2 .1 & 2.2.4.6.14 & 7.4.3 & 3 & $\begin{array}{l}2.3 .1 \\
2.5 .3\end{array}$ \\
\hline 8.2 .2 & 2.2.4.6.16 & $\begin{array}{c}6.1 .2 \\
6.13 \\
8.1\end{array}$ & 3 & $\begin{array}{l}2.3 .3 \\
2.5 .2\end{array}$ \\
\hline 8.2 .3 & 2.2.4.6.15 & NR & 1.2 .5 & 2.5 .2 \\
\hline 8.3 & NR & NR & $\begin{array}{l}1.3 .2 \\
1.3 .3\end{array}$ & $\begin{array}{l}2.3 .4 \\
2.5 .3\end{array}$ \\
\hline 8.4 .1 & 2.2.4.6.28 & 8.1 & 1.2 .1 & $\mathrm{NR}$ \\
\hline 8.4 .2 & 2.2.4.6.28 & NR & 1.3 .3 & NR \\
\hline 8.4 .3 & $\begin{array}{l}2.2 .4 .6 .27 \\
\text { 2.2.4.6.2.28 }\end{array}$ & NR & $\mathrm{NR}$ & NR \\
\hline 8.5 .1 & 2.2.4.6.24 & $\begin{array}{l}8.1 \mathrm{a} \\
8.1 \mathrm{~b}\end{array}$ & 1.3 .3 & $\begin{array}{l}2.3 .5 \\
2.5 .3 \\
2.5 .6 \\
2.6 .3 \\
\end{array}$ \\
\hline 8.5 .2 & NR & NR & 1.2 .4 & $\begin{array}{c}2.5 .6 \\
3.2\end{array}$ \\
\hline 8.5 .3 & NR & NR & NR & NR \\
\hline 8.5 .4 & NR & NR & 2.1.1 & NR \\
\hline 8.5 .5 & $\mathrm{NR}$ & NR & 1.2 .2 & NR \\
\hline 8.5 .6 & 2.2.4.6.26 & NR & $\mathrm{NR}$ & 2.5 .2 \\
\hline 8.6 & NR & NR & 2.1.1 & 2.5 .2 \\
\hline 8.7 & NR & NR & 2.1.1 & 2.5 .3 \\
\hline
\end{tabular}

Source: Own development.

From the check phase, the correlated requirements correspond to the performance assessment, which facilitates senior management and process leaders, to structure the presentation of consistent and integral results in the efforts developed, from the activities of assessment and monitoring, in this sense is determined what, how and when it is subject to supervision, measurement, analysis and assessment, in order to deliver information that shows without bias the performance of the specifications that support the management. 
Table 5. Correlated clauses - CHECK

\begin{tabular}{|c|c|c|c|c|}
\hline $\begin{array}{l}\text { NTC ISO } \\
9001: 2015\end{array}$ & $\begin{array}{c}\text { OHSMS - DECREE } \\
1072 / 2015\end{array}$ & $\begin{array}{l}\text { NTC ISO } \\
14001: 2015\end{array}$ & MECI:2014 & MIPG:2012 \\
\hline Clause & Clause & Clause & Clause & Clause \\
\hline 9.1.1 & NR & 9.1.1 & 2.1.1 & $\begin{array}{c}2.3 .4 \\
3.1\end{array}$ \\
\hline 9.1 .2 & NR & NR & 3 & $\begin{array}{c}2.3 .1 \\
2.3 .4 \\
2.3 .5 \\
3.1\end{array}$ \\
\hline 9.1.3 & $\begin{array}{l}2.2 .4 .6 .33 \\
\text { 2.2.4.6.2.22 }\end{array}$ & 9.1 .2 & 1.2 .4 & $\begin{array}{c}2.3 .4 \\
2.5 .1 \\
3.1\end{array}$ \\
\hline 9.2 & $\begin{array}{l}2.2 .4 .6 .29 \\
\text { 2.2.4.6.30 }\end{array}$ & 9.2 & 2.2 .1 & 3.1 \\
\hline 9.3 & 2.2.4.6.31 & 9.3 & $\begin{array}{l}1.2 .4 \\
2.2 .1\end{array}$ & $\begin{array}{l}3.1 \\
3.2\end{array}$ \\
\hline
\end{tabular}

Source: Own development.

As a final phase that indicates the start of a new cycle, the requirements corresponding to the improvement are integrated from the act. These facilitate taking advantage of opportunities for improvement that are detected in the assessment phase, to face non-conformities, corrective actions and assume strategies for continuous improvement. The sequence of continuous improvement of the organization allows to be considered as an innovation reference for other entities.

Table 6. Correlated Clauses - ACT

\begin{tabular}{|c|c|c|c|c|}
\hline $\begin{array}{c}\text { NTC ISO } \\
\text { 9001:2015 }\end{array}$ & $\begin{array}{c}\text { OHSMS - DECREE } \\
1072 / 2015\end{array}$ & $\begin{array}{c}\text { NTC ISO } \\
14001: 2015\end{array}$ & MECI:2014 & MIPG:2012 \\
\hline Clause & Clause & Clause & Clause & Clause \\
\hline \multirow{2}{*}{10.1} & 2.2 .4 .6 .34 & 10.1 & $\begin{array}{c}2.2 .1 \\
2.3 .1\end{array}$ & 2.5 .4 \\
\hline 10.2 & 2.2 .4 .6 .33 & 10.2 & 2.2 .1 & NR \\
\hline 10.3 & 2.2 .4 .6 .34 & 10.3 & 2.3 .1 & 2.5 .1 \\
\hline
\end{tabular}

Source: Own development. 
The correlation matrix allowed to identify that the EMS in requirement 8.2 "Preparation and response to emergencies" is not susceptible to correlation, taking into account that it applies exclusively to the environmental management of the organization. The same situation occurs with the OHSMS, in its articles 2.2.4.6.25 "Prevention, preparation and response to emergencies" and 2.2.4.6.32 "Investigation of incidents, work accidents and occupational diseases", which are specific to occupational safety and health system and therefore do not correlate with any requirements of the QMS.

In order to obtain correlation and reliability criteria of the matrix, four surveys were designed with the interest of measuring the degree of perception of the correlation of requirements of the NTC-ISO 9001:2015 model compared to the interactions of the other requirements of the systems to be integrated.

The selection of the variables involved was made considering that the dependent variable obtains a nonnormalized distribution, that is, its value at all times is constant in each of the evaluation items of the survey. On the other hand, the values that are designated in the dependent variables correspond to ordinal data with values determined by intervals (Hernández, Fernández \& Baptista, 2014).

This way, the requirements of the QMS were established as dependent, ordinary and continuous variable and the requirements of the other models as independent variables, determining that by statistical use the measurement levels should consider nonparametric variables (Hernández, Fernández \& Baptista, 2014), applying their own statistical methods for non-parametric analysis, in order to establish the correlation between the study variables, following the precepts of Hernández, Fernández \& Baptista who propose the application of Spearman's correlation (2014, p. 326), as a criterion of statistical acceptance. The measurement of respondents' perception was determined using a Likert 1-5 scale, with the rating indicated in table 7:

Table 7. Survey rating scale

\begin{tabular}{|c|c|}
\hline Rating & Meaning \\
\hline 1 & No correlation \\
\hline 2 & Scarce correlation \\
\hline 3 & Acceptable correlation \\
\hline 4 & Moderate correlation \\
\hline 5 & Total correlation \\
\hline
\end{tabular}

Source: Own development.

The data collected whose coding is made taking advantage of the assessment of the Likert scale, are subjected to the statistical treatment, which according to Hernández, Fernández \& Baptista allow to determine the instrument's reliability as accepted criteria, facilitating by applying Cronbach's alpha to establish reliability in a range of 0 to 1 , where the result 0 indicates that it is not reliable and result 1 indicates that it is totally reliable, determining as acceptance value of reliability 0,8 (2014, p. 296). The results obtained are presented in table 8 :

Table 8. Results of Cronbach's alpha reliability

\begin{tabular}{|c|c|c|c|c|}
\hline Results & $\begin{array}{c}\text { NTC ISO 9001:2015 } \\
\text { vs. OHSMS - Decree } \\
1072 / 2015\end{array}$ & $\begin{array}{c}\text { NTC ISO 9001:2015 vs. } \\
\text { NTC-ISO14001:2015 }\end{array}$ & $\begin{array}{c}\text { NTC ISO 9001:2015 } \\
\text { vs. MECI:2014 }\end{array}$ & $\begin{array}{c}\text { NTC ISO 9001:2015 } \\
\text { vs. MIPG:2012 }\end{array}$ \\
\hline Cronbach's alpha & 0.8625 & 0.9387 & 0.9496 & 0.9289 \\
\hline
\end{tabular}

Source: Own development. 
Another criterion of reliability applied to the instrument is the correlation coefficient, constituted as a tool for the quantitative description of the magnitude and direction of the relationship between different phenomena (Hungler \& Polit, 2003). Spearman's coefficient is established as a statistical method, as it facilitates the correlation measure for variables at an ordinal measurement level, which measures the interaction of a dependent variable with an independent variable using statistically Likert scales. The coefficient varies from -1.0 (perfect negative correlation) to +1.0 (perfect positive correlation), and the value 0 as absence of correlation between the hierarchized variables (Hernández, Fernández \& Baptista, 2014, pp. 238-241). The results are presented in table 9:

Table 9. Results of Spearman's Correlation

\begin{tabular}{|l|c|c|c|c|}
\hline \multicolumn{1}{|c|}{ DIMENSION } & $\begin{array}{c}\text { NTC ISO 9001:2015 } \\
\text { Vs. OHSMS- Decree } \\
1072 / 2015\end{array}$ & $\begin{array}{c}\text { NTC ISO 9001:2015 Vs. } \\
\text { NTC-ISO14001:2015 }\end{array}$ & $\begin{array}{c}\text { NTC ISO 9001:2015 } \\
\text { Vs. MECI:2014 }\end{array}$ & $\begin{array}{c}\text { NTC ISO 9001:2015 } \\
\text { Vs. MIPG:2012 }\end{array}$ \\
\hline $\begin{array}{l}\text { Spearman's Correlation } \\
\text { minimum value }\end{array}$ & 0.8897 & 0.90147 & 0.94547 & 0.9255 \\
\hline $\begin{array}{l}\text { Spearman's Correlation } \\
\text { maximum value }\end{array}$ & 0.9318 & 0.9715 & 0.9834 & 0.9689 \\
\hline
\end{tabular}

Source: Own development.

\section{CONCLUSIONS}

As a result of this research, it is established that there is a correlation between the requirements of the ISO technical standards with the normative models of the Colombian State, verified from the correlation matrix validated by 42 respondents, with results that demonstrate high reliability according to Cronbach's alpha of 0.86 and high correlation according to Spearman's coefficient of 0.88 . The matrix is therefore a guideline that facilitates management integration in public entities, recognizing the common elements of the requirements that are susceptible to the integration of management systems, in each phase of the spiral of continuous improvement.

The strategy to address the correlation of requirements of the NTC-ISO 9001:2015, NTC-ISO 14001: 2015, OHSMS Decree 1072 of 2015, MECI:2014 and
MIPG:2012, as evidenced in tables 3, 4, 5 and 6, takes as an integrating axis the NTC-ISO 9001:2015, identifying that this system has immersed the MECI:2014 and MIPG:2012 models, however, there are exceptions in the correlation of the requirements of the NTC-ISO 14001:2015 (clause 8.2) and OHSMS Decree 1072 of 2015 (articles 2.2.4.6.25 and 2.2.4.6.32) due to the focus and specificity of each of them.

The correlation matrix therefore becomes a guideline that facilitates management integration of public entities, recognizing the common elements of the requirements that are susceptible to integration of management systems in each phase of the spiral of continues improvement from the technical standard ISO 9001:2015.

The establishment of the interactions of the requirements, allows to identify that of the 47 main clauses of the QMS, only requirement 8.5.3 "Property belonging 
to external customers or suppliers" does not correlate with any of the other models included in the correlation matrix.

It is recommended for future research, to address within the correlation matrix the update of the MIPG version 2 and consider other technical standards and normative models from the high-level structure, such as the ISO/IEC 27001 information security management systems (ISO, 2013) or the Information Security and Privacy Model (MSPI) of the Ministry of Information Technologies and Communications (MINTIC, 2016), among others.

\section{REFERENCES}

Bernardo, M. (2014). Integration of management systems as an innovation: a proposal for a new mode. Journal of Cleaner Production, 82, 132-142. doi: 10.1016/j.jclepro.2014.06.089

Bernardo, M., Simon, A., Tarí, J. J., \& Molinan, J. F. (2015). Benefits of management systems integration: a literature review. Journal of Cleaner Production,94, 260-267. doi: 10.1016/j.jclepro.2015.01.075

Bernardo, M., Gianni, M., Gotzamani, K., \& Simon, A. (2017). Is there a common pattern to integrate multiple management systems? A comparative analysis between organizations in Greece and Spain. Journal of Cleaner Production. 151, 121-133. doi: 10.1016/j.jclepro.2017.03.036

Bonilla, A., \& Martínez, J. A. (2015). Propuesta de instrumento para medir el nivel de integración de los sistemas de gestión en orranizaciones colombianas certificadas en ISO 9001, ISO 14001 y OHSAS 18001. (Tesis de maestría). Bogotá: Universidad Santo Tomás.
Camisón, C., Cruz, S., y González, T. (2006). Gestión de la calidad: conceptos, enfoques, modelos y sistemas. Madrid: Pearson Educación, S. A. Recuperado de http://g00.gl/5yTIgq

Centro Latinoamericano de Administración para el Desarrollo. [CLAD]. (2009). Carta Iberoamericana de Participación Ciudadana en la Gestión Pública. Caracas. Recuperado de http://old. clad. org/documentos/declaraciones/carta-iberoame ricana-de-participacion-ciudadana

Congreso de la República. (9 de junio de 2015). Por la cual se expide el Plan Nacional de Desarrollo 20142018 Todos por un nuevo país. Ley 1753. Diario Oficial n. : 49.538.

Departamento Administrativo de la Función Pública. [DAFP]. (2014). Manual Técnico del Modelo Estándar de Control Interno para el Estado Colombiano MECI 2014. Bogotá D. C.: Recuperado de http://www.funcionpublica.gov.co/documents/418537/506911/Manual+T\%C3\%A9cnico+ del+Modelo+Est\%C3\%A1ndar+de+Control+Interno+para+el+Estado+Colombiano+MECI+2014 1065a3838-cc9f-4eeb-a308-21b2a7a040bd

Hernández, R., Fernández, C., y Baptista, P. (2014).Metodología de la investigación: Roberto Hernándes Sampieri, Carlos Fernándes Collado y Pilar Baptista Lucio (6. ${ }^{a}$ ed.). México D. F.: McGraw-Hill Education.

Hidalgo, J. (19 de septiembre de 2016). Comunicación telefónica con el Director de Gestión y Aseguramiento del Instituto Mexicano de Normalización. En L. A. Sarmiento (Entrevistador). México D. F.

Hungler, B. P., y Polit, D. F. (2003). Investigación cientifica en ciencias de la salud: principios y métodos, (6). México D. F.: McGraw-Hill interamericana. 
Instituto Colombiano de Normas Técnicas y Certificación. [ICONTEC]. (2013). Norma Técnica Colombiana NTC-ISO-IEC 27001, Tecnología de la información.

Técnicas de seguridad. Sistemas de gestión de la seguridad de la información. Requisitos. Bogotá: Icontec.

Instituto Colombiano de Normas Técnicas y Certificación. [ICONTEC]. (2015). Norma Técnica Colombiana NTC 14001, Sistemas de Gestión Ambiental. Requisitos con orientación para su uso. Bogotá: Icontec.

Instituto Colombiano de Normas Técnicas y Certificación. [ICONTEC]. (2015a). Norma Técnica Colombiana NTC 9001, Sistemas de gestión de la calidad. Bogotá: Icontec.

International Organization for Standardization. [ISO]. (2014). Anexo SL de las directivas ISO/IEC parte 1. Consolidated ISO Supplement - Procedures specific to ISO (Fifth edition). Retrieved from http://www.iso. org/sites/directives/directives.html

Ministerio de Tecnologías de la Información y las Comunicaciones. [MINTIC]. (11 de marzo de 2016). Modelo seguridad y privacidad de la información Versión 3.0.1. Recuperado de http://estrategia.gobiernoenlinea.gov.co/623/articles-8260_recurso_1.pdf

Ministerio del Trabajo. (26 de mayo de 2015). Decreto Único Reglamentario del Sector Trabajo. Decreto 1072. Diario Oficial n. : 49.523.

Organization for Economic Cooperation and Development. [OCDE]. (13 de octubre 2016). Inversión pública más eficiente en Colombia. Recuperado de https://www.oecd.org/gov/mlg-colombia-summary-es.pdf

Presidencia de la República de Colombia. (3 de diciembre de 2012). Lineamientos generales para la integración de la planeación y la gestión. Decreto 2482. Diario Oficial n. : 48.634.

Presidencia de la República de Colombia. (21 de mayo de 2014). Actualización del Modelo Estándar de Control Interno. Decreto 943. Diario Oficial n. : 49.158.

Rebelo, M. F., Santos, G., \& Silva, R. (2014). A Methodology to Develop the Integration of the Environmental Management System with Other Standardized Management Systems. Computational Water, Energy, and Environmental Engineering, 3, 170-181. doi: 10.4236/cweee.2014.34018

Santos, S. G. (2017). Valider y confiabilidad del cuestionario de calidad de vida SF-36 en mujeres con Lupus, Puebla. (Tesis de licenciatura). Puebla: Benemérita Universidad Autónoma de Puebla. Recuperado de http:/www.fcfm.buap.mx/assets/docs/docencia/tesis/ma/GuadalupeSantos Sanchez.pdf

Vieira, T., Ferreira, L. C., \& De Oliveira, O. J. (2016). Evolution of integrated management systems research on the Journal of Cleaner Production: Identification of contributions and gaps in the literature. Journal of Cleaner Production, 139, 1234-1244. doi: 10.1016/j.jclepro.2016.08.159 